\title{
Impacts of Land Use and Cover Changes on Transhumant Pastoralism in Sudanian Zones of Burkina Faso, West Africa
}

\author{
Charles L. Sanou ${ }^{1,2 *}$, Nouhoun Zampaligré ${ }^{3,4}$, Daniel N. Tsado ${ }^{1}$, André Kiema ${ }^{3}$, Yssouf Sieza ${ }^{5}$ \\ ${ }^{1}$ Federal University of Technology, Minna, Nigeria \\ ${ }^{2}$ West African Science Service Centre on Climate Change and Adapted Land Use, Ouagadougou, Burkina \\ Faso \\ ${ }^{3}$ Institut de l'Environnement et de Recherches Agricoles, station de Farako-ba, Burkina Faso \\ ${ }^{4}$ Centre International de Recherche-Développement sur l'Elevage en zone Subhumide (CIRDES), \\ Bobo-Dioulasso, Burkina Faso \\ ${ }^{5}$ Ministère des Ressources Animales et Halieutiques du Burkina Faso, Boucle du Mouhoun \\ *Corresponding author: sclamoussa@gmail.com or sanou.c@edu.wascal.org
}

Received: May 17, 2018

doi:10.5296/jas.v6i3.13474
Accepted: June 1, 2018

URL: https://doi.org/10.5296/jas.v6i3. 13474

\begin{abstract}
This research aimed to investigate how the rapid land use and cover changes is affecting pastoral resources and practices within Kompienga province in Sudanian zone of Burkina Faso. To achieve this aim, Landsat images data of years 1989, 2001, 2013 and 2015 were retrieved and analysed. Images were acquired following the path 193 and row 52, from Landsat-5 Thematic Mapper (TM), Landsat-7 Enhanced Thematic Mapper Plus (ETM+) and Landsat-8 Operational Land Imager (OLI). Images processing were done using 350 training sample for both; the purpose of supervised classification and accuracy assessment. Random Forest Algorithm (RFA) procedures in R-Software (version 3.3.2) were used for images classification. Furthermore, survey data were collected through group discussions and individual interviews with a 271 head of household respondents (pastoralists and agro-pastoralists) to investigate respondents' perceptions on land uses and covers changes and its impacts on their pastoral and agro pastoral resources and animal husbandry practices. Results showed that Land use dynamics was characterized by an increase in croplands at an average rate of $46.7 \%$ per year, between 1989 and 2015. On the contrary a decline of pasture lands was observed since 2001 at an average rate of $6.0 \%$ per year. Similar trends in land uses changes were observed by interviewed respondents who depicted an increase in cropping lands (98.5\% of respondents) to the detriment of pasture lands $(97.8 \%$ of respondents). To overcome these land use/land cover changes and it subsequent consequences, respondent pastoralists and agro pastoralists have developed local adaptations strategies.
\end{abstract}




\section{Macrothink

Thus, some measures are still needed at government level to sustain local pastoralist and agro-pastoralist efforts and strengthen their adaptive capacity.

Keywords: Land use/covers changes, pastoralist and agropastoralists perceptions, Pastoralism, climate change and Sudanian zone 


\section{Introduction}

Protected areas and agroforestry parklands are the two major land-use types in West African ecosystems (Nacoulma et al., 2011). Each of these land-use types are characterized by a specific goal. Indeed, protected areas aim is the conservation of biodiversity while parklands are intended for anthropogenic utilisation through clearance practices for cropping, livestock grazing and forests products exploitation. Anthropogenic activities underpin therefore changes in landscape leading to the apparition of some given land cover types to the expense of others. This process is fuelled by population growth which leads to increasing pressure on natural resources in a context of West Africa, where the majority of people livelihoods directly depend on natural resources exploitation. Indeed, with a growing population, the need for food will increase accordingly leading to high demand for agricultural lands. Therefore, between 1980 and 2005, food production has increased from 67 to 216 million tonnes (Blein et al., 2008). However, this increase is mostly dependent on croplands areas expansion (229\%) rather than the increase in crop yields (42\%) (Blein et al., 2008). The consequences of such expansion are rapid declines in natural vegetation covers such forests and savannahs (Lambin et al., 2003, Leblanc et al., 2008), leading to a widespread land use and land cover dynamics (Boone et al., 2016). Agricultural land expansion is the dominant lands dynamics in West-Africa (Wood et al., 2004; Braimoh and Vlek 2005 and Judex et al. 2003). In a similar way, since the 1970s, Burkina Faso is experiencing every year, croplands expansion to the detriment of forest. The expansion of cropland and the decline in forest cover are associated with the country population growth (Ouedraogo, 2010; Boone et al., 2016). Agricultural lands expansion occurred mainly in the western and southern areas of the country, including Kompienga Province located in the Sudanian zone of Burkina Faso where climate and other environmental conditions are relatively good compared the Sahelian zone.

Due to the relative abundance of the natural resources including agricultural lands the Sudanian zones of the country are the preferred destination zones of Sahelian farmers and herders, migrating in search of good arable lands and rich pastures for their livestock and agricultural activities. Thus, the pressure on lands and other natural resources is gradually increasing leading to environment degradation. According to Ouedraogo et al. (2009), the degradation is underpinned by immigration of farmers and their extensive agricultural practices into the Sudanian zones, which if not well managed, will seriously degrade the environment. Gonin and Gautier, (2015) found that in Burkina Faso, there is a rapid regression of pastoral areas (rangelands and transhumance routes) to the benefice of croplands namely cotton cultivation which have been promoted by the state development policies. Mobile herders' territorialities in Burkina Faso have been compromised since independence and until now there is a lack of appropriate legislation on pastoral lands in the country. Furthermore, through satellite images analysis Gonin and Gautier, (2015) showed a reduction of rainy season rangelands from $58 \%(54,400 \mathrm{~km} 2)$ of the total area of western Burkina Faso in 1992 to $48 \%(45,200 \mathrm{~km} 2)$ in 2002. Sulieman and Elagib (2012) through LULC changes analysis within El Gedaref region, have shown a global rapid increase of agricultural and bare land areas compared to vegetation areas which in exception of one site of study area, experimented a rapid decrease in vegetation cover during 1979-2008. This 
drastic change in LULC is affecting and reducing significantly grazing resources. It appeared that land-use policy is the major driver of the observed agricultural rapid expansion at the detriment of rangeland. Similarly, Kima et al., (2016), in Boulgou province, found a rapid conversion of woody savannah, shrub and grass savannah to croplands. Moreover, Soulama, (2015) indicated that the partial wildlife reserve of Pama (Kompienga Province) and its outskirts experienced a reduction in dense plant formations, and an increase in savannah vegetation, bare soils and field-fallow mosaics. However, LULC changes analysis was performed over a shorter period (2001-2013) than what is intended by the current research (1989-2015) that will give a recent overview of study area. Given that within pastoral and agro-pastoral system, forests and savannahs units constitute grazing lands for pastoral herds, the decline in such units will compromise forage availability and affect accordingly their productive and reproductive performances. Pastoral herding in Kompienga province, is currently facing increased challenges. Among these challenges there are the reduction of grazing land size, the obstruction of livestock routes, the reduction of watering points and the recrudescence of conflicts between land users. These challenges affect livestock production and reproductive performances and finally the livelihoods of pastoral communities. Land use and cover dynamics seem to be one of the major drivers of these challenges. Thus, scientific evidence of the impacts of land-use dynamics on pastoral practices and resources will be useful for policy makers to take informed decision and actions to overcome those challenges. The current research aims to investigate how the rapid land use and cover changes is affecting pastoral resources and practices within Kompienga province in Sudanian zone of Burkina Faso.

\section{Methodology}

\subsection{Study sites characteristics}

The study was carried out in Kompienga province (figure 1), located in the south eastern Burkina Faso, between $0^{\circ} 30^{\prime} 4.96 "$ and $1^{\circ} 22^{\prime 2} 22.25^{\prime \prime}$ longitude Est and 1056'16.85" and $11^{\circ} 27^{\prime 2} 21.09 "$ latitude North. The province covers an area of $6998 \mathrm{~km}^{2}$ (INSD, 2014) about $1 / 3$ of which is occupied by forest reserves and about 1/3 (223,000 ha) by wildlife reserves (Gomgnimbou et al., 2010). It represents $2.6 \%$ of the country's area $(274200 \mathrm{Km} 2)$.

The climate of the province is Sudanian, characterized by an alternation of rainy season (May to September/October) and a dry season (October/November to April). The dry period is dominated by a dry and warm wind known as harmattan (Dipama et al., 2011; Soulama, 2016). While the rainy season is characterized by moist winds (monsoon) and the annual rainfall fluctuates between 700 and $1000 \mathrm{~mm}$ on average. The average annual temperatures range from $30.7^{\circ}$ to $39.7^{\circ} \mathrm{C}$ for the maximum and $17.5^{\circ} \mathrm{C}$ to $26.3^{\circ} \mathrm{C}$ for the minima. The population of Kompienga is estimated about 75867 (38 357 men and 37510 women) with 13239 households (INSD, 2008).

The leached tropical ferruginous soils predominate, sometimes with hydromorphic soils found along rivers (Mbayngone et al., 2008). The flora is characterised by two types of vegetations in the eastern region: savannahs and dry forests. The forest is dominated by Anogeissus leiocarpus, Pterocarpus erinaceus, Stereospermum kunthianum, Tamarindus 


\section{Macrothink}

Journal of Agricultural Studies

ISSN 2166-0379 2018, Vol. 6, No. 3

indica, Diospyros mespiliformis, Acacia polyacantha and Acacia sieberiana. Savannahs are generally shrubby, sometimes wooded or grassy in the alluvial plains dominated by woody species such as Combretum glutinosum, C. collinum, Vitellaria paradoxa, Terminalia avicennioides, Acacia dudgeoni, A. gourmaensis, A. hockii, Crossopteryx febrifuga, Piliostigma thonningii, Combretum nigricans and Lannea acida. The dominant herbaceous species are Andropogon pseudapricus, Andropogon gayanus, Aristida kerstingii, Andropogon chinensis and Hyparrhenia involucrata (MBayngone, 2008).

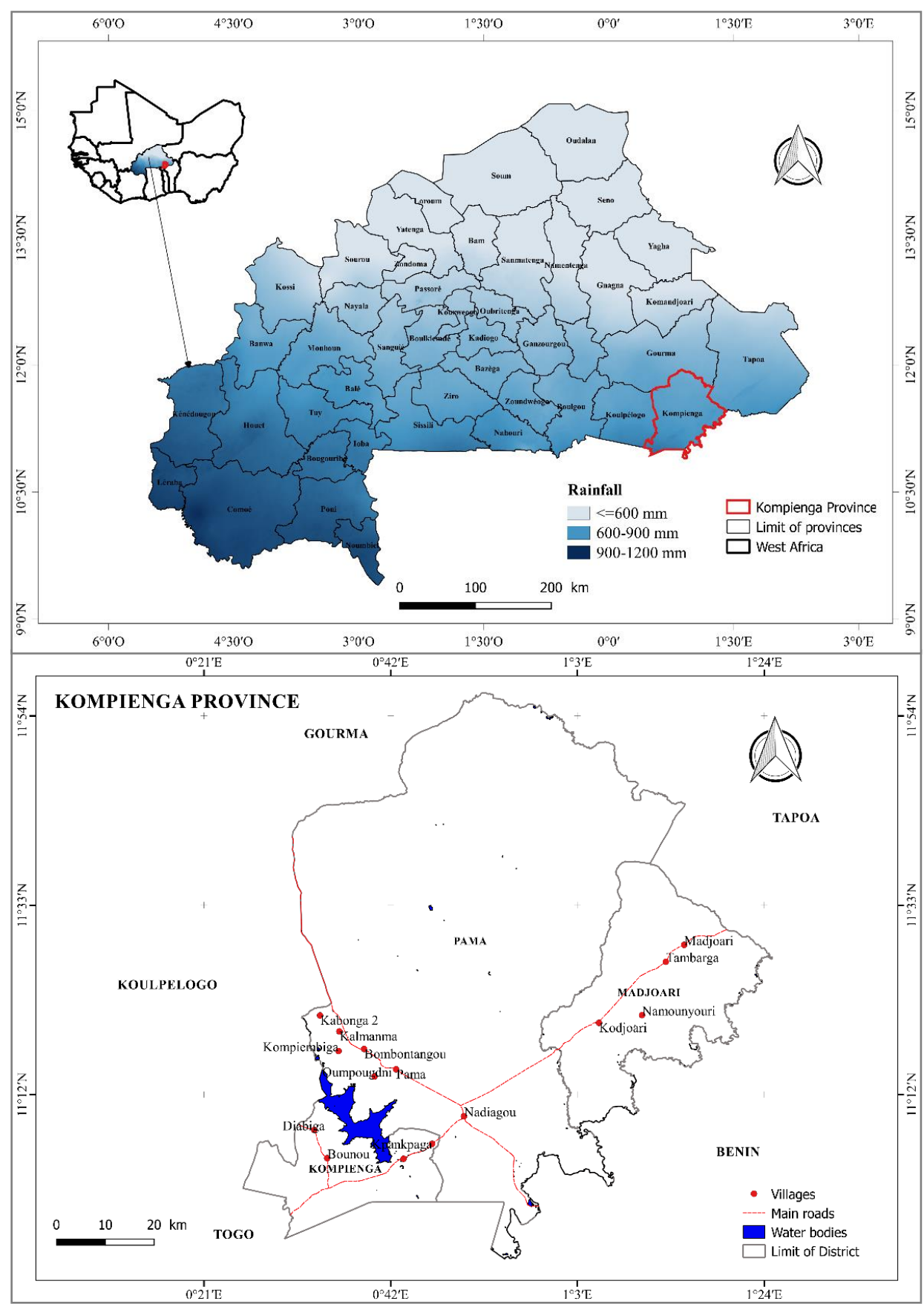

Figure 1. Study sites (data source: adapted from Institut Geographique du Burkina Faso) 
2.2. Methods for data collection

\subsubsection{Data collection}

For the purpose of this study we used two approaches for data collection, first we analyse land uses and covers changes by using satellites images in R software 3.3.2 and QGIS 2.18.3. software. Secondly, we conducted household survey and focus group discussion to investigate the pastoralists and agro pastoralists perceptions on land uses and covers changes and its impacts on their pastoral and agro pastoral resources and animal husbandry practices.

Satellites images were acquired from United States Geological Survey (USGS) website for the path 193 and row 52, from Landsat-5 Thematic Mapper (TM), Landsat-7 Enhanced Thematic Mapper Plus (ETM+) and Landsat-8 Operational Land Imager (OLI). The periods of interest for images analysis covers three sets of periods $(1989,2001,2013)$ with twelve years intervals. However, the image of year 2015 was also analysed because major changes in land use were noticed after 2013. Training sample were collected over the study area for both the purpose of classification and accuracy assessment. The collection was performed within chosen training areas representing the identified land use land cover classes. For the purpose of a better accuracy, ground truth data were collected avoiding pixels over a transition area between two or more classes. Each sample unit was geo-localised by taking GPS points as much as possible at its centre. These points were collected between June and July 2017 and land use and cover units were photographed. 


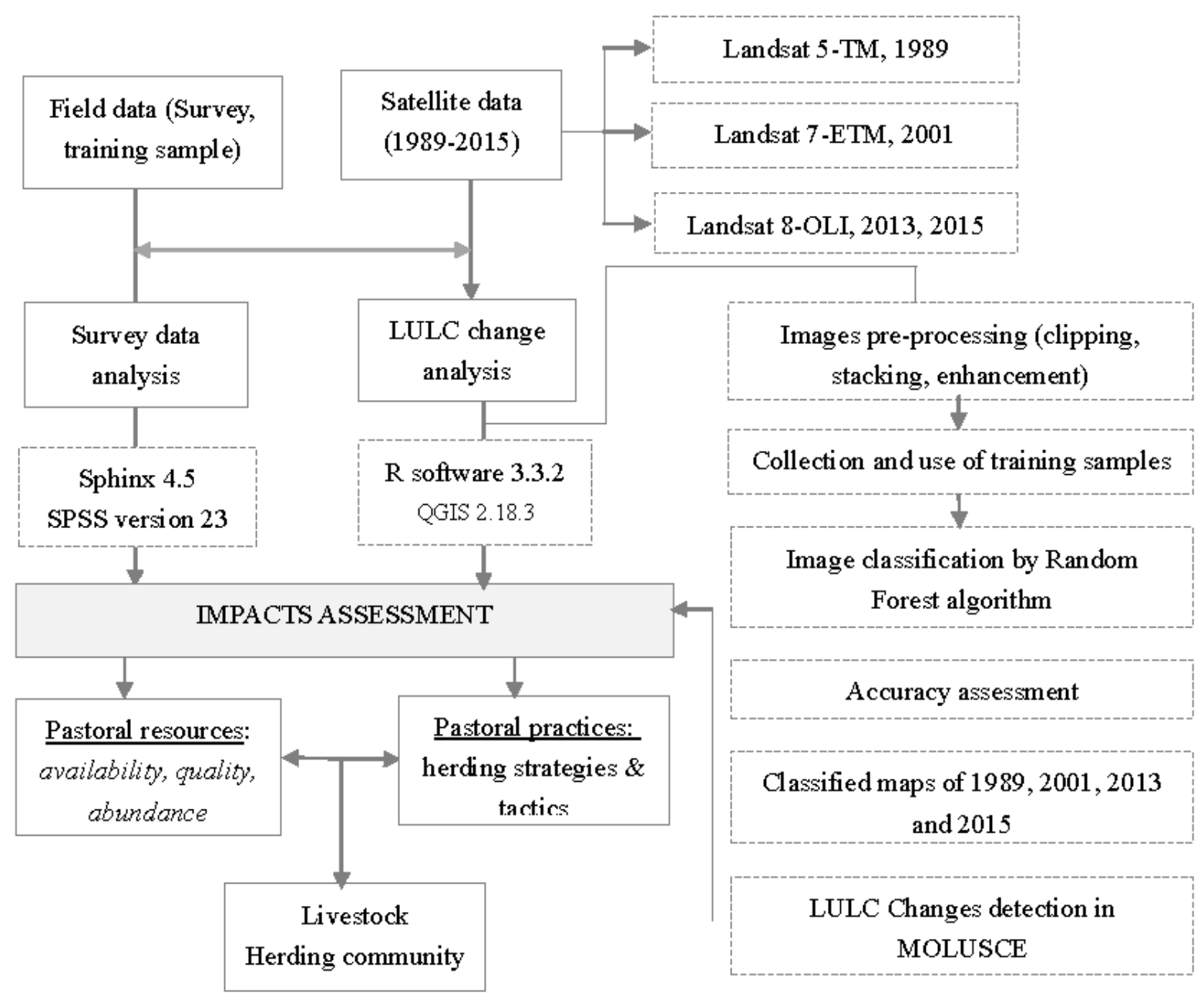

Figure 2. Methodological flow chart

The household survey data was collected in twelve (12) villages and 271 head of pastoralists and agro-pastoralists households were interviewed. Criteria for the selection of the villages were: (i) importance of herding (ii) recurrence of conflicts among land users; (iii) constraints in rangelands and other pastoral resources conditions. The targeted respondents were pastoralists, owners of more than 25 cattle; and agro-pastoralists, those owning between 10 and 25 cattle. Therefore, in each village, the development committee was involved to identify respondents that meet the set criteria. On this basis all the herders that fulfilled the set criteria and where available at the time of survey were interviewed. The interview was conducted based on: socio-economic characteristics of the respondents; respondents' perceptions on the impacts of land use and cover changes on availability and access to key pastoral resources; respondents' perceptions on land use and cover changes on pastoral practices and livelihoods and respondents' adaptation measures to overcome the impacts of land use and cover changes. Prior to the household survey group discussions on land use dynamics were conducted within the 12 villages experiencing reduction in grazing lands and related conflicts between herders and crop farmers. Each group was composed of 5-10 persons aged at least 45 years. This is 


\section{Macrothink}

Journal of Agricultural Studies

ISSN 2166-0379

2018, Vol. 6, No. 3

essential for observations or analysis of changes in land use and cover dynamics. Survey data collection was carried out between June and July 2017.

\subsubsection{Data analyses}

\section{Satellite data analysis}

QGIS 2.18.3 software was used for bands combination and images enhancement process using the Semi-Automatic Classification Plugin (SCP). The enhancement was done through Red-Green-Blue (RGB) composite using the bands NIR, Red and Green. Image classification used the Random Forest Algorithm (RFA) run in R-Software (version 3.3.2). This classification technique is one of newest proposed by Breiman, (2001). It was chosen because of its good level of correctness. Indeed, Random Forest has an unexcelled accuracy among current algorithms (Kulkarni and Lowe, 2015 and 2016) with an overall accuracy and Kappa coefficient up to $96.25 \%$ and 0.95 respectively.

The time series images were used to investigate changes in the landscape, particularly in the pastoral resources (pasture lands, water). It helped to observe how range lands have been affected or depleted over the last decades. The change detection was performed using MOLUSCE (Modules for Land Use Change Evaluation) plugin in QGIS environment. This plugin provides a set of algorithms for land use change simulations among which Artificial Neural Networks (ANN) was used. It allows the generation of statistics table showing land use/cover change (LUC) areas and the transition matrix depicting the proportions of pixels that changed from one land use/cover type to another. QGIS software was also used for vectorization, images clipping and land use land cover maps production for years 1989, 2001, 2013 and 2015.

In the process of classification accuracy assessment, training samples were used to verify the correctness of the classification. For this purpose, these samples were divided in to two subgroups: $70 \%$ used to perform images classification and the remaining $30 \%$ used for validation. The result gives a confusion matrix that compare the cartographic results and the data collected in the field. From the confusion matrix, common measures of accuracy assessment were derived such as user's accuracy, producer's accuracy, overall accuracy and Kappa coefficient. These accuracy assessment measures were computed using the Table 1 below to derive required formulas (Foody, 2002). R software 3.3.2 was used in this accuracy assessment. 
Table 1. Principle of accuracy computation

\begin{tabular}{|c|c|c|c|c|c|c|}
\hline \multicolumn{7}{|c|}{ Actual LULC Units } \\
\hline \multirow{6}{*}{ 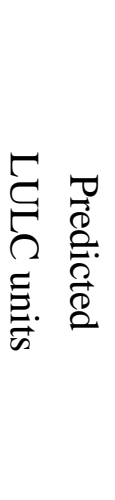 } & & A & B & $\mathrm{C}$ & D & Sum \\
\hline & A & $\mathrm{n}_{\mathrm{AA}}$ & $\mathrm{n}_{\mathrm{AB}}$ & $\mathrm{n}_{\mathrm{AC}}$ & $\mathrm{n}_{\mathrm{AD}}$ & $\mathrm{n}+\mathrm{A}$ \\
\hline & B & $\mathrm{n}_{\mathrm{BA}}$ & $\mathrm{n}_{\mathrm{BB}}$ & $\mathrm{n}_{\mathrm{BC}}$ & $\mathrm{n}_{\mathrm{BD}}$ & $\mathrm{n}+\mathrm{B}$ \\
\hline & $\mathrm{C}$ & $\mathrm{n}_{\mathrm{BC}}$ & $\mathrm{n}_{\mathrm{CB}}$ & $\mathrm{n}_{\mathrm{CC}}$ & $\mathrm{n}_{\mathrm{CD}}$ & $\mathrm{n}_{+\mathrm{C}}$ \\
\hline & $\mathrm{D}$ & $\mathrm{n}_{\mathrm{DA}}$ & $\mathrm{n}_{\mathrm{DB}}$ & $\mathrm{n}_{\mathrm{DC}}$ & $\mathrm{n}_{\mathrm{DD}}$ & $\mathrm{n}_{+\mathrm{D}}$ \\
\hline & Sum & $\mathrm{n}_{+\mathrm{A}}$ & $\mathrm{n}_{+\mathrm{B}}$ & $\mathrm{n}_{+\mathrm{C}}$ & $\mathrm{n}_{+\mathrm{D}}$ & $\mathrm{n}$ \\
\hline
\end{tabular}

Percentage correct $=\frac{\sum_{k=1}^{q} n_{k k}}{n} \times 100$

$$
\text { User's accuracy }^{\prime}=\frac{n_{i i}}{n_{\mathrm{i}+}}
$$

Kappa coefficient $=\frac{n \sum_{k=1}^{q} n_{k k}-\sum_{k=1}^{q} n_{k+} n_{+k}}{n^{2}-\sum_{k=1}^{q} n_{k+} n_{+k}} \quad$ Producer's accuracy $=\frac{n_{i i}}{n_{+\mathrm{i}}}$

The increase or decrease rate of croplands areas and grazing lands areas was estimated using the formula:

$$
A P C R=\frac{\frac{\left(l u l C_{\text {present }}-l u l C_{\text {past }}\right)}{\text { lul } C_{\text {post }}} \times 100}{N}
$$

Where: $A P C R=$ annual percentage change rate in land use and cover

lulcpresent $=$ present or recent area (ha) of land use and cover

lulcpast $=$ past area (ha) of land use and cover

$\mathrm{N}=$ number of years between the two-land use and cover

Then the free grazable area were computed by the subtraction of protected area from the total area of vegetation in the province.

$\mathrm{FGA}=\mathrm{TVA}-\mathrm{PA}$

FGA (ha): Free Grazable Area

TVA (ha): Total Vegetation Area

PA (ha): Protected Area

The total area of vegetation was computed for each year by addition of the units constituted 
by Gallery Forest /Wet area, Woody Savannah, Shrub and grassland. The total protected area was computed using information from the National Topographic Data Base of Burkina Faso (IGB \& IGN/IGN-FI, 2015) and National Decrees instituting Zones of Hunting Interest within eight villages of Kompienga province (Decrees of 2010 for Pama and Kompienbiga, Decree of 2013 for Folpodi and decrees of 2014 for Tambarga, Kodjoari, Matambima, Namouyouri, Madjoari).

\section{Survey data analysis}

The survey data were analysed using Statistical Package for Social Science (SPSS version 23) software, descriptive statistics were used for variables on LULC changes impacts on pastoral farming system. Pearson's chi-square $(\chi 2)$ Statistical test were used to analyse respondents' statements related to respondents' adaptations measures to LULC changes. Statistical test significance was set at $5 \%(\mathrm{p}<0.05)$. Chi-square $(\chi 2)$ value is computed using the following formula:

$$
\chi^{2}=\Sigma \frac{\left(f_{\mathrm{o}}-f_{\mathrm{e}}\right)^{2}}{f_{\mathrm{e}}}
$$

where $\chi^{2}$ is the Chi-square; fo denotes the frequency of the observed data and $f e$ is the frequency of the expected values.

Participatory maps produced during groups discussions were analysed together with respondents putting a light on land use and cover dynamics and their drivers within each village. Respondents were asked to illustrate changes in LULC between 1987 and 2017. For this purpose, the following steps were followed: (i) the representation on a "kraft paper" of the village territory with the current major existing resources (houses, roads, water bodies, bore hole, wells, forests, farms lands, livestock's routes, grazing lands...); (ii) the representation of a past picture of the village territory with the majors existing resources; (iii) a participatory analysis was done to give an idea on how the main LULC units have changed over the last three decades and their implications in herders' access to pastoral resources. An investigation was done from transhumant pastoralists over their constraints on their way to transhumance.

\section{Results}

\subsection{Respondents household socio demographic characteristics}

The majority of respondents $(98.2 \%)$ were male and $90.8 \%$ were over 30 years of age; and $58.3 \%$ are pastoralists and $41.1 \%$ agro-pastoralists (table 2). This situation indicates that within Kompienga province the herding activity is mainly done by men and the majority are involved in pastoralism.

Fulani were the major ethnic group involved in the study $(62.0 \%)$ followed by the Gourmatché (21.0\%) and the Mossi (17.0\%). This is explained by the socio-economic characteristics of each ethnic group. Indeed, Fulani group are identified as pastoral communities while mossi and Gourmatché group constituted agro-pastoralists and 
agriculturalists.

About $65.3 \%$ of respondents were migrants, $30.6 \%$ native of the survey villages and $4.1 \%$ transhumant pastoralist in transit every year. Majority of interviewees were illiterate $(88.2 \%)$, $6.3 \%$ were literate against $4.8 \%$ and $0.7 \%$ which are respectively primary school and secondary school level. Beside livestock keeping, $79.3 \%$ of interviewees asserted to have agriculture as secondary activities. Others activities such fishing, pretty trade, artisan and casual worker concerned $9.4 \%, 7.6 \%, 2.8 \%$ and $0.9 \%$ respectively. It appears that livestock farmers are more and more interested in agriculture within the province. That may be due to the increasing challenges that pastoral farming is facing over the recent years such as the reduction of grazing lands sizes. The changes in climate conditions may also explain that situation.

Table 2. Socio-economic characteristics of the respondents $(n=271)$

\begin{tabular}{lclc}
\hline \multicolumn{1}{c}{ Variable } & Frequency $(\%)$ & \multicolumn{1}{c}{ Variable } & Frequency (\%) \\
\hline Gender & 98.2 & Age range & 9.2 \\
Male & 1.8 & More than 30 years & 90.8 \\
Female & & Respondents' origin & \\
Ethnic group & 62.0 & Native & 30.6 \\
Fulani & 21.0 & Migrant & 65.3 \\
Gourmantché & 17.0 & Transhumant transiting & 4.1 \\
Mossi & & Main activity & \\
Household size & 50.6 & Pastoralists & 58.3 \\
Less than 10 & 49.4 & Agro-pastoralists & 41.1 \\
More than 10 & & Second activity & \\
Level of education & 88.2 & Agriculture & 79.3 \\
Illiterate & 6.3 & Fishing & 9.4 \\
Literate & 4.8 & Trade & 7.6 \\
Primary school & 0.7 & Worker & 0.9 \\
Secondary school & & Artisan & 2.8 \\
\hline
\end{tabular}

\subsection{Observed land uses and covers changes from satellites images analyses (1989-2015)}

Good overall accuracies ( $84.7 \%$ to $90.9 \%$ ) were obtained for each classified maps and were within the range of [79.78\% - 94.59\%] reported by Sulieman and Elagib, (2012) during LULC classification along livestock seasonal migration routes within eastern Sudan. Furthermore, the obtained Kappa values (0.79 to 0.88) indicate a substantial to strong agreement between ground truth data and land use and cover units depicted on thematic maps according the categorisation of Landis and Koch (1977). 


\section{Macrothink

The results show that the unit Gallery Forest/wet area and the group constituted by Woody Savannah/Shrub/Grassland were the most dominant land cover unit over years 1989 (45.5\% and $40.4 \%$ ) and 2001 (41.61\% and $47.01 \%$ ). This group remained predominant in 2013 (79.1\%) and 2015 (75.8\%). Similarly, Soulama et al. (2015), reported that Woody Savannah and Shrub/Grassland was the most predominant LULC category over the province between 2001 and 2013. Croplands that occupied one of the smallest area $(0.8 \%)$ in 1989 have increased to became the second largest LULC unit (10.6\%) after Woody Savannah/ Shrub/Grassland (75.8\%). The increased rate of croplands areas is estimated at $46.7 \%$ on average per year. The proportion of Forest Gallery/Wet area has experienced a continuous regression of their area since 1989. Urban/Settlement and water were the smallest unit over all the years under study with respectively amplitudes of $0.2 \%-0.3 \%$ and $1.5 \%-1.9 \%$ of the province land areas. Between 1989-2001, 2001-2013, 2013-2015 and 1989-2015, croplands have gradually increased in areas partly to the detriment of pasture lands (Woody Savannah/Shrub/Grassland). Comparing the periods between 1989 and 2001 (12 years), 2001-2013 (12 years) and 2013-2015 (2 years) the highest increase in cropland was noticed over 2013-2015 (9.8\%). These results mean there is a recent increase in anthropic pressures (human activities) on land over the last five years. This might be due to the recent decline in climate conditions. Under worse climatic conditions, soils fertility is often affected and farmers are prone to increase cropland to maintain the level of production. The second reason for rapid increase (46.7\% on average per year) in cropping areas over the five last years, may also be due to cash crop development and cultivation facility using herbicides.

Gallery Forest/Wet area unit have decreased over each period respectively at a rate of $-3.9 \%$, $-35.1 \%,-0.6 \%$ and $-39.7 \%$. It appears therefore, that the degradation of these land use units was more visible after 2001. Urban unit experienced a slight increase between 1989-2001 $(+0.1 \%)$ and over 2001-2013 (+0.04\%) and was constant between 2013-2015. The decrease in water over periods 1989 and 2001, 2013 and 2015, 1989 and 2015 and the increase in water over 2001-2013 maybe due to the variability of rainfall over these periods. Finally, the ensemble Savannah/Shrub/Grassland has increased over periods 1989-2001 (+6.6\%), 2001-2013 (+32.1\%) and has decreased over the period 2013-2015 (-3.3\%). The increase in these units might be essentially due to the degradation of Gallery Forest/Wet areas while the decrease rate noticed maybe due to its partial conversion into cropland area over the last five years (Figure 3). 


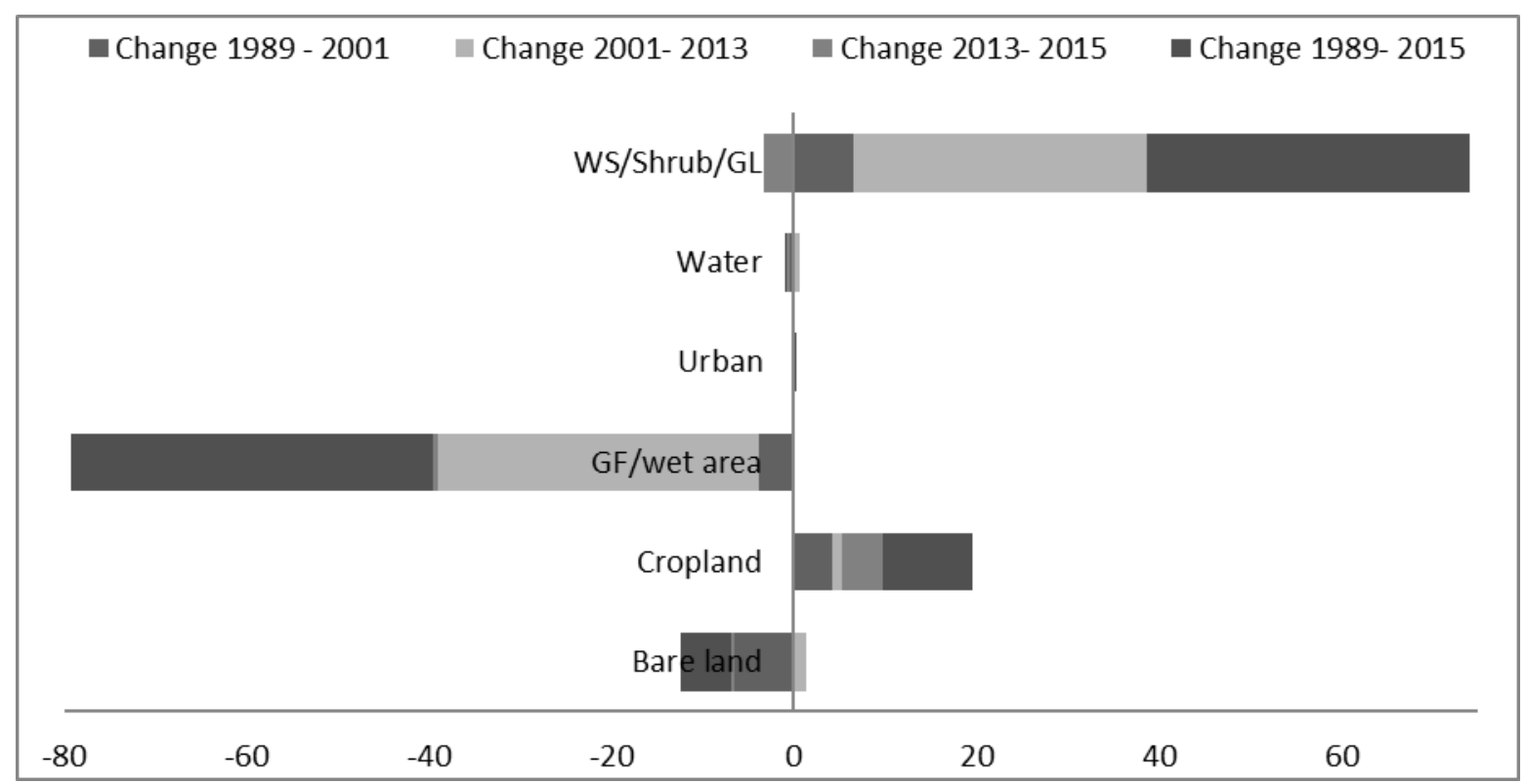

Figure 3. Land use and cover changes within Kompienga province from 1989 to 2015.

(GF: Gallery Forest; WS: Woody Savannah, GL: Grassland)

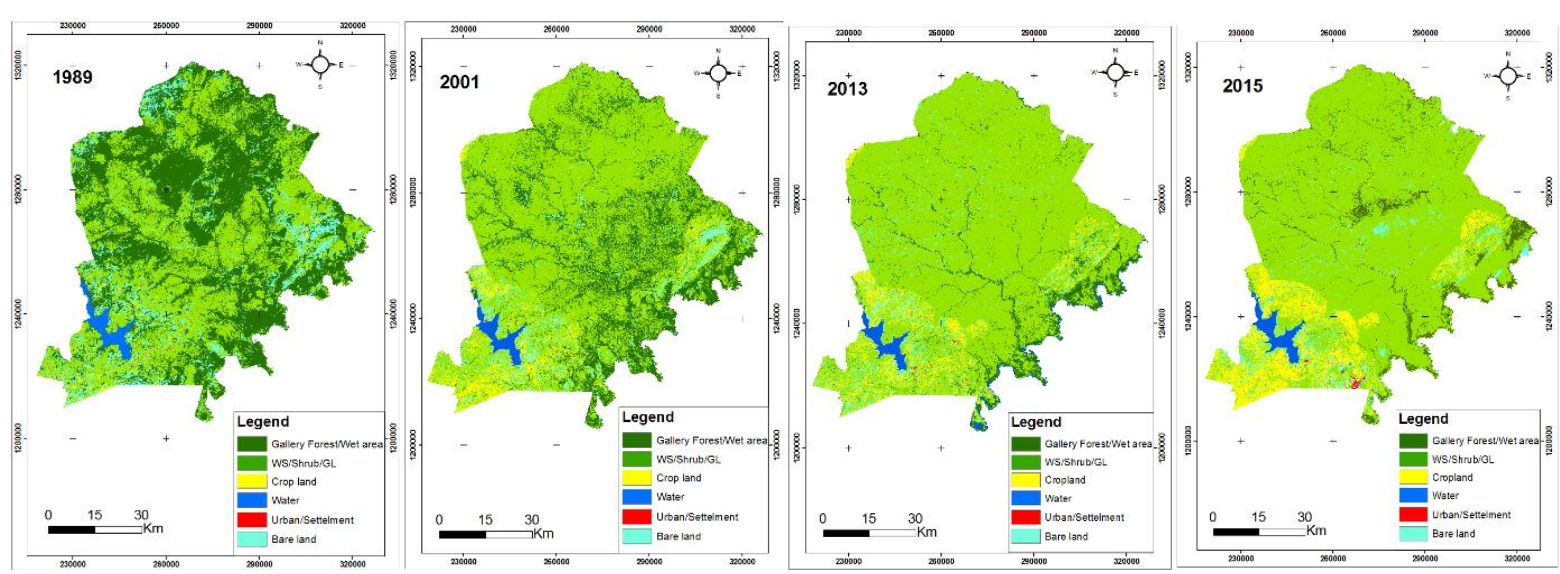

Figure 4. Land use and cover maps of Kompienga province from 1989 to 2015

Kompienga province is one of the biodiversity conservation areas of Burkina Faso. This situation explains the predominance of vegetation compared to other land cover units due to the existence of large protected areas in the province. The protected forests which in sum cover about 555,967.4 hectares (IGB \& IGN/IGN-FI, 2015) constituted: (i) parts of total wildlife reserve of Singou, Madjoari, Konkombouri; and (ii) Partial Wildlife Reserve of Pama. Besides these forests a second kind of protected lands were created after year 2010 in the province which constituted the village areas of Hunting interest measuring 4,577.9 hectares. Therefore, out of the total areas of 600,553.3 hectares of vegetation in 1989, 555,967.4 hectares $(92.6 \%)$ were protected and about $44,585.84$ hectares $(7.4 \%)$ were accessible to 


\section{Macrothink}

livestock.

In $2001,10.2 \%$ (63,104.2 ha) of the total vegetated areas $(619,071.7 \mathrm{ha})$ were grazable while about 555,967.4 ha $(89.8 \%)$ were still protected. In 2013 and 2015, protected areas increased up to $560,545.3$ ha and grazing lands amounted respectively $6.3 \%(37,617.2$ ha) and $1.8 \%$ (10,090.2 ha) of the vegetation areas (Figure 5). As a result, a gradual decline in area available for free grazing has been observed since 2001 at an average rate of $6.0 \%$ per year. This is far higher than the reduction rate of the vegetation $(0.96 \%$ per year) found by Ouedraogo et al. (2010) within Sissili Province of Burkina Faso between 1986 and 2006. This situation coupled with the decline in climate conditions underpinned the increasing pressure and competition for the residuals lands between crop farmers and herders. The consequences are the increasing occurrence of conflicts, the increase in cross-borders mobility of herds with also their corollary of conflicts within reception zones of transhumant herders.

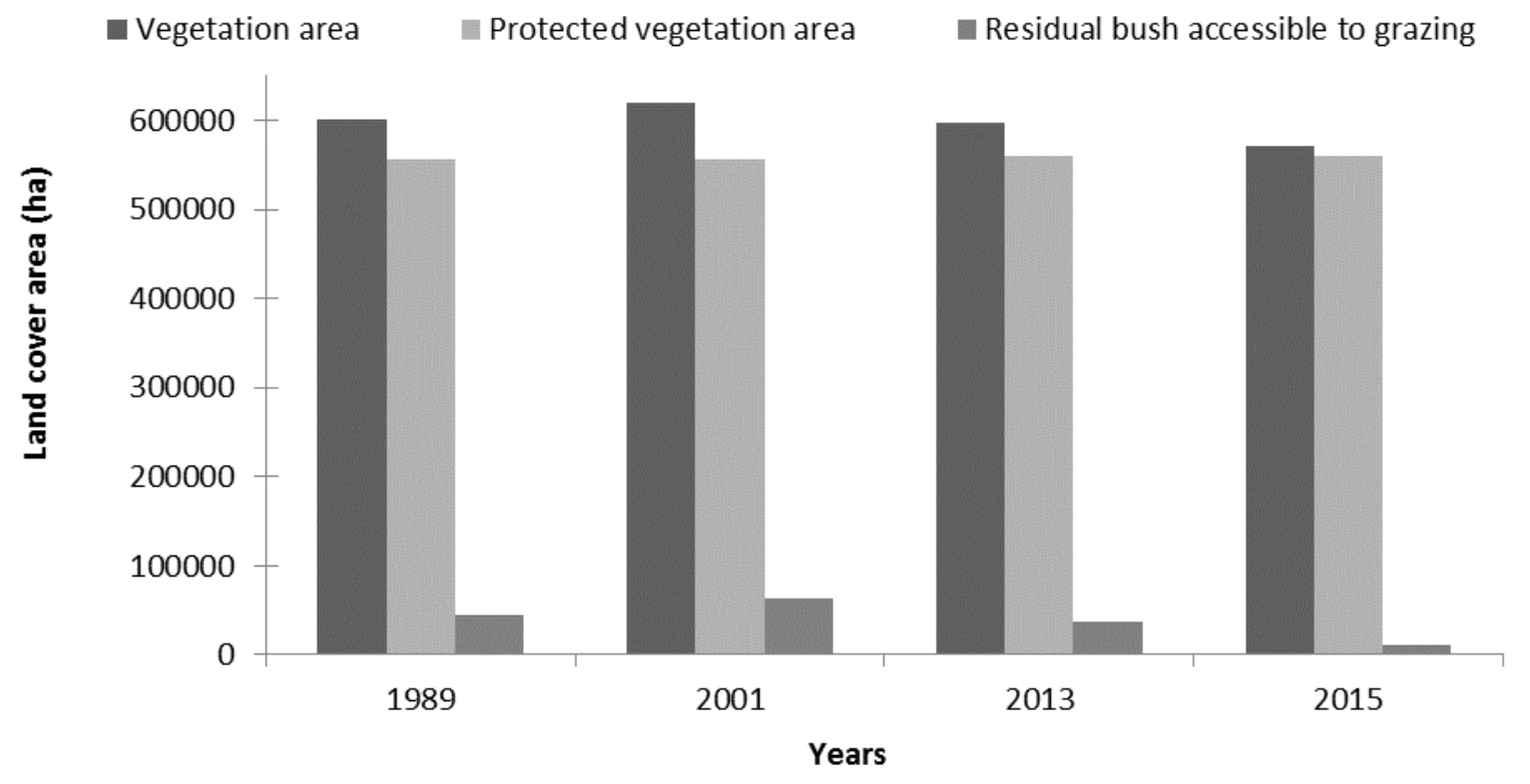

Figure 5. Observed trends of grazing lands, total vegetation area and protected areas within Kompienga Province from 1989 to 2015

\subsection{Main constraints and challenges of pastoralism in the study area}

From respondents perspective, the most important constraints of pastoral herding in Kompienga province is pasture degradation and losses of forage species (26\%), followed respectively by : (i) insufficient number of grazing reserves in Burkina Faso (21\%); (ii) the interdiction to graze within protected areas (14\%); (iii) the lack of forage collection and conservation tools (12\%); (iv) insufficient watering points $(6 \%)$, animal diseases $(6 \%)$, long distance travels to access pasture (6\%); (v) violent conflicts and losses of animals (5\%) and (vi) excessive taxes payment during transhumance (4\%). 
Pasture degradation and losses of palatable forage species are due to recent land use and cover dynamics in the study area. In respondents' perceptive, within Kompienga province, great changes were observed between 1987 and 2017. These changes concern a rapid conversion of pastoral lands into croplands. That situation is reflected in the declarations of Diao Hamadi, a herder of 40 years old, living in the village of Mamanga: "in previous years, there were enough space for our animals that circulated and grazed freely unlike nowadays, due to a continuous conversion of pastoral spaces into croplands ». In the same way, Diande Boureima, 67 years old, living in the Pastoral Zone Kaboanga; asserted that: "Before, here there were enough spaces for our animals that circulated and grazed freely unlike nowadays, due to a continual conversion of pastoral spaces into croplands".

Such dynamics might affect negatively both pastoral resources and practices respectively through the decline of available forage biomass amount and the increasing pressure on fodder trees, changes in mobilities calendar and paths. Moreover, changes in land use and cover in the province have fuelled the occurrence of violent conflicts between land users namely crop farmers and herders. Finally, many pastoralists have moved their herds to Togo or Ghana due to a drastic reduction of pastoral areas.

Changes in climate conditions of Kompienga province is also cited by respondent as affecting negatively pastoral resources during the last 30 years. Pastoralists and agro-pastoralists asserted that the changing climate have also led to disappearance of certain herbaceous and woody forages species (100\% of respondents), decline of herbaceous and woody forages nutritive quality (97.8\% of respondents) and Shortage of pasture biomass. This situation affects negatively the production performance of livestock in the pastoral system which directly relies on the productivity of natural grassland.

These results are corroborated by Zampaligré et al., (2013) findings across different zones of Burkina Faso. These authors found from pastoralists and agro-pastoralists a shrinkage of grazing areas and the decline of forage resources over the past 20 years. Furthermore, similar results were found by Breusers (2001), Sawadogo (2011) and Kiema et al. (2013). They attest that a decreased rainfall affects negatively the quality of pasture biomass and their productivity, inducing ultimately, the disappearance of most palatable species within grazing lands. Moreover, Gentle and Thwaites (2016) also found that climate change is affecting pastoral resources through decreases in water and pasture, replacement of palatable grasses by invasive weeds. In the same way, it was found within Kajiado region of Kenya, that pastoral resources were negatively impacted by climate change (Maina and Mundia, 2016).

Within the province, the disappearance of numerous forage species was depicted. A total of thirty (30) identified species were depicted to be threatened or to have already disappeared from the pastoral areas. The forage species that is more threatened or that have completely disappeared in some grazing lands is Andropogon gayanus (day $y$ e). From the individual interview with the 271 pastoralists and agro-pastoralists 124 respondents (45.7\%) indicated that this forage species is about to completely disappear from the grazing areas, while they indicated is presence within the protected area.

Population growth (41\%), and cash crop production such as cotton $(38.5 \%)$, are far the most 
important drivers of pasture degradation. These drivers fuel land uses and cover dynamics as an immediate cause of pasture degradation ahead of rainfall decrease, increase in livestock, use of herbicide and Bush fire. However, the gradual herbicide utilization by farmers appears today to be, one of the most preoccupant issues threatening biodiversity and a sustainable development in the province. The use of herbicide plays also a paramount role in croplands expansion, because a farmer is able to burn out at least 2 hectares a day using an herbicide called " $K A L A C H$ ". In this process three immediate consequences are :(i) a rapid change in land use and cover, (ii) a progressive extinction of soils micro-organism essential for soil fertility; (iii) an interruption of the development cycle of annual grasses. Indeed, herbicide misuse could block the reproduction of some species due to a discontinued production of seeds burnt out during herbicide application. This certainly explains the extinction of fodder species reported by pastoralists and agro - pastoralists within Kompienga province. The declaration of Diallo Idrissa, 47 years old, living in the Kaboanga pastoral zone, is a perfect illustration: "Following the proliferation of croplands, two very popular herbaceous species have completely disappeared from the rangelands: dayye (A. gayanus) which stimulates dairy production and kankalgahi (A. africana) which is very nutritious for livestock. Misuse of pesticides is one of the causes".

Besides the decline in forage biomass and rapid croplands expansion, there is also a high risk of animal poisoning due to water contamination, the persistence of pesticides in soil and on grass. Furthermore, conflicts become frequent around grazing reserves and along transhumance routes both in Kompienga and host countries. Indeed, over the last decades Kompienga province have experienced violent conflicts events: in Nadiagou and Pama in 2013 and 2014 respectively. Furthermore, conflicts in year 2015 were particularly violents and affected seriouly pastoral communities of villages of Mamanga, Diapienga, Tibadi, Folpodi and Nimoutingou. These conflicts affected 106 pastoral househods, and losses registeered consisted in 343 houses, 80 tons of forage, 3.9 tons of concentrated feed and about 35 heads of small ruminants killed (ZATE, 2015). Similarly, transhumant herders are facing more and more fatal violent conflicts in recent years within host contries (Togo, Benin Republic and Ghana). Indeed, within Togo, since 2013 the village of Djarakpana expeienced violent conflicts with human casualities and losses of livestock. Moreover, violent conflicts were experienced in Borgou and Bassar in 2014 and 2016 respectively. In addition, villages of Kante, Namon and Kouka also experienced violent conflicts in year 2017. Furthermore, conflicts were registered within the village of Datori in Benin Republic and Guschiegu village in Ghana in 2013 and 2016 respectively (Sanou et al., 2018)

\subsection{Impacts of land use and cover changes on availability and access to key pastoral resources}

In respondents' perspective, the most significant dynamics in land use and cover within Kompienga province during the last decades are the increase in croplands $(98.5 \%$ of respondents) to the detriment of grazing lands (97.8\% of respondents). Similarly Kimiti et al. (2016) indicated from respondents perceptions, that the main changes in pastoral resources over the last 40 years was the reduction of grazing lands due to the expansion of croplands and settlements. Moreover, respondents believe that land use and cover changes is seriously 
affecting the availability and access to key pastoral resources (Figure 6).

As a result of these changes in LULC, $82.3 \%$ of the respondents are of the view that LULCC (Land Use and Land Use Cover Changes) reduce access to pasture lands; $82.3 \%$ indicated that LULCC resulted in the reduction of grazing areas and some respondents (55\%) reported obstructions of transhumance routes. These results were similar to that of Kimiti et al. (2016), who reported significant changes $(\mathrm{p}<0.001)$ in the range resources. The changes included a significant reduction in pasture $(\chi 2=75.89, \mathrm{df}=3, \mathrm{p}<0.001)$ and livestock's routes $(\chi 2=$ $66.77, \mathrm{df}=3, \mathrm{p}<0.001)$ while croplands increased significantly $(\chi 2=124.55$, df $=3 \mathrm{p}$ $<0.001)$.

Furthermore, respondents' perceptions corroborate the findings of different authors (Western and Nightingale, 2003; Western and Maitumo, 2004; Western, 2006; Kioko and Okello, 2010; Msoffe et al., 2011; Kioko et al., 2012) who reported a decline in forage biomass and a reduction of pastoral areas to the benefit of Settelment and Croplands. Finally, there were $36.5 \%$ and $17.5 \%$ who mentioned reduced access to watering points and lands degradation respectively. Land use and cover dynamics consequences are really worrying over the last decades. Within some villages during the rainy season, livestock are confined in rocky areas unsuitable for agriculture. Otherwise, the increasing search of arable land for cash crop development is aggravating the competition for land between herders and crop farmers. Pastoral areas are gradually converted by crop farmers in Kompienga province with their corollary of conflicts. Respondents pointed out that the future of pastoralism in Kompienga will be affected mainly by population growth and cropland expansion rather than by climatic conditions. Moreover, pressure intensification on land is likely to further deteriorate the relationship between crops farmers and herders. In this condition, most of pastoralists, despite the dangers they face in host countries, could migrate permanently to Ghana, Togo and Benin Republic. This sends a strong signal to planners and policymakers to take urgent action to stem the negative implications that future land use and cover dynamics could bring about in the study area.

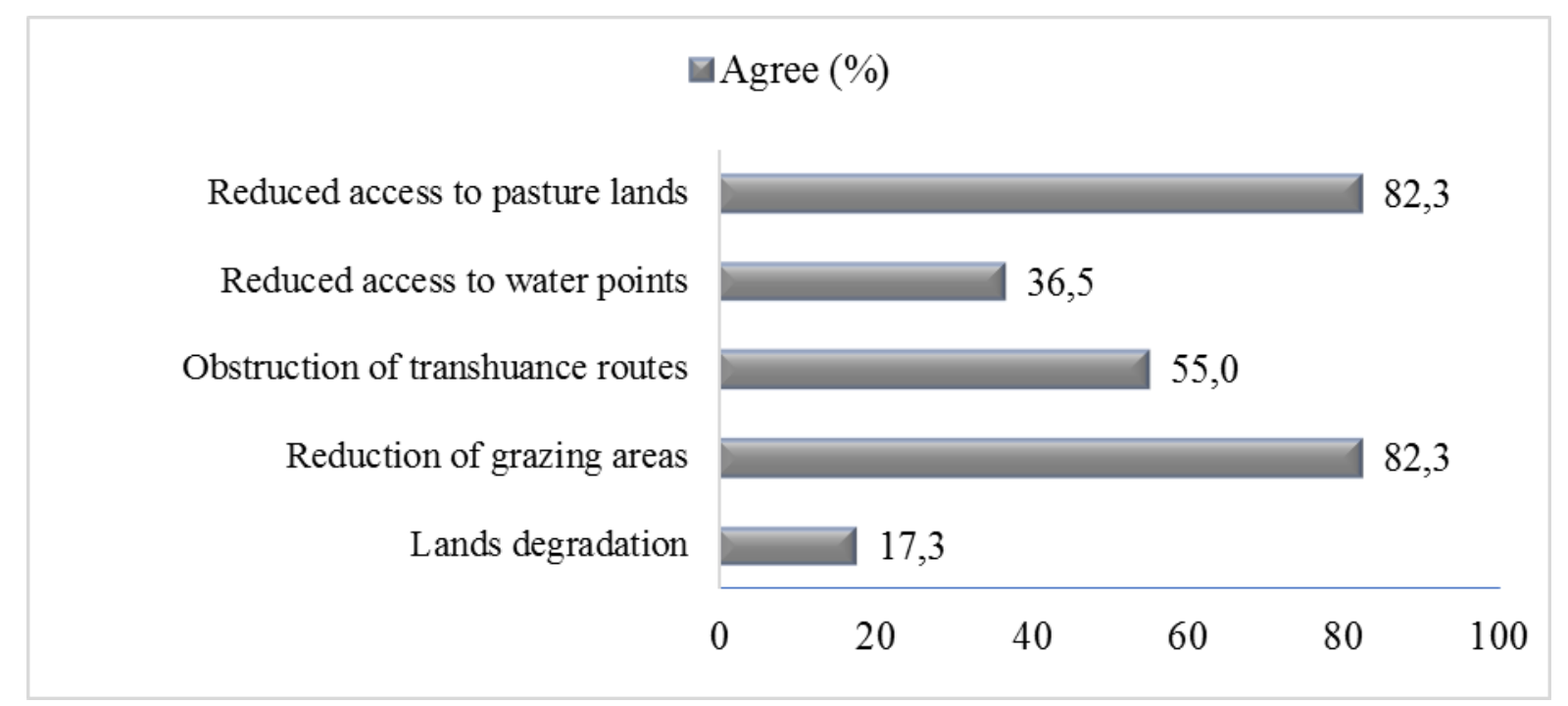

Figure 6. Respondents perceived impacts of LULC dynamics on pastoral resources $(n=271)$ 


\subsection{Impact of land use and cover changes on pastoral practices and livelihoods}

The observed changes in land use and cover over the last decades within Kompienga province affected pastoral practices (Figure 7). The changes reported by respondents are an increase use of forage resources from browse trees $(71.2 \%)$, in night grazing of transhumant herds $(90.4 \%)$, migrations in unusual destinations $(38.4 \%)$, modification in transhumance routes and schedule $(29.2 \%$ and $52.8 \%$ respectively).

The use of fodder trees is a common practice undertaken by herders especially during the dry season in a perspective to improve livestock diet. Leaves, fruits/pods and flowers of fodder trees constitute rich sources of nutrients that can be used during the dry season in supplement to dry fodder of low nutritive quality during this period. However, the frequency and duration of use of these trees has increased today. This is mainly due to the insufficiency of grazing areas and climate change as well. Early cessation of rainy season and increases in temperature rates reported by respondents have a negative impact on forage availability. Thirty years ago, livestock had enough grazing areas compared to the current years characterized by a rapid cropland expansion. Moreover, according to respondents the forage in the pasture dry out earlier and earlier over the recent years. In such circumstances, herders have limited choice to provide suitable feed to livestock. They either fall back on ligneous forage or migrate to other areas even unusual. In the distress of lack of fodder and water for herds, the only information on the forage availability guides them, whatever the destination. Thus, they sometime risk their lives by migrating to unusual areas as long as they are certain to find grazing lands there. This phenomenon is more and more perceived by the breeders.

Furthermore, from respondent perspective thirty years ago, enough space was available for grazing. Kompienga province was playing more a role of reception zone for transhumant herds (from northern and central part of the country and Niger) rather than a role of transit zone that it is playing today. Over the recent years, resources scarcity forced herders of the province to adopt gradually cross-border transhumance. With climate change, the scarcity of pastures during the dry season is occurring earlier than before, and pastoralists are thus forced to adjust the transhumance schedule and, moreover, they adjust the path followed according to the availability of pastures. In addition, over the province, the international transhumance route is occupied in several levels by croplands. Faced with this situation, herders are obliged to follow alternative routes, for example along electricity network where human activities are prohibited. Finally, thirty years ago according to respondents there were no need to look after the herds during the night because enough space was available for grazing with very few likelyhood that herds' night grazing affects crops. On the contrary, herders asserted that today they must make more effort to look after herds during the night to avoid herds to get into the growing farms. Thereof, they can avoid clashes with crops farmers with whom social cohabitation is not the best in the current years. 


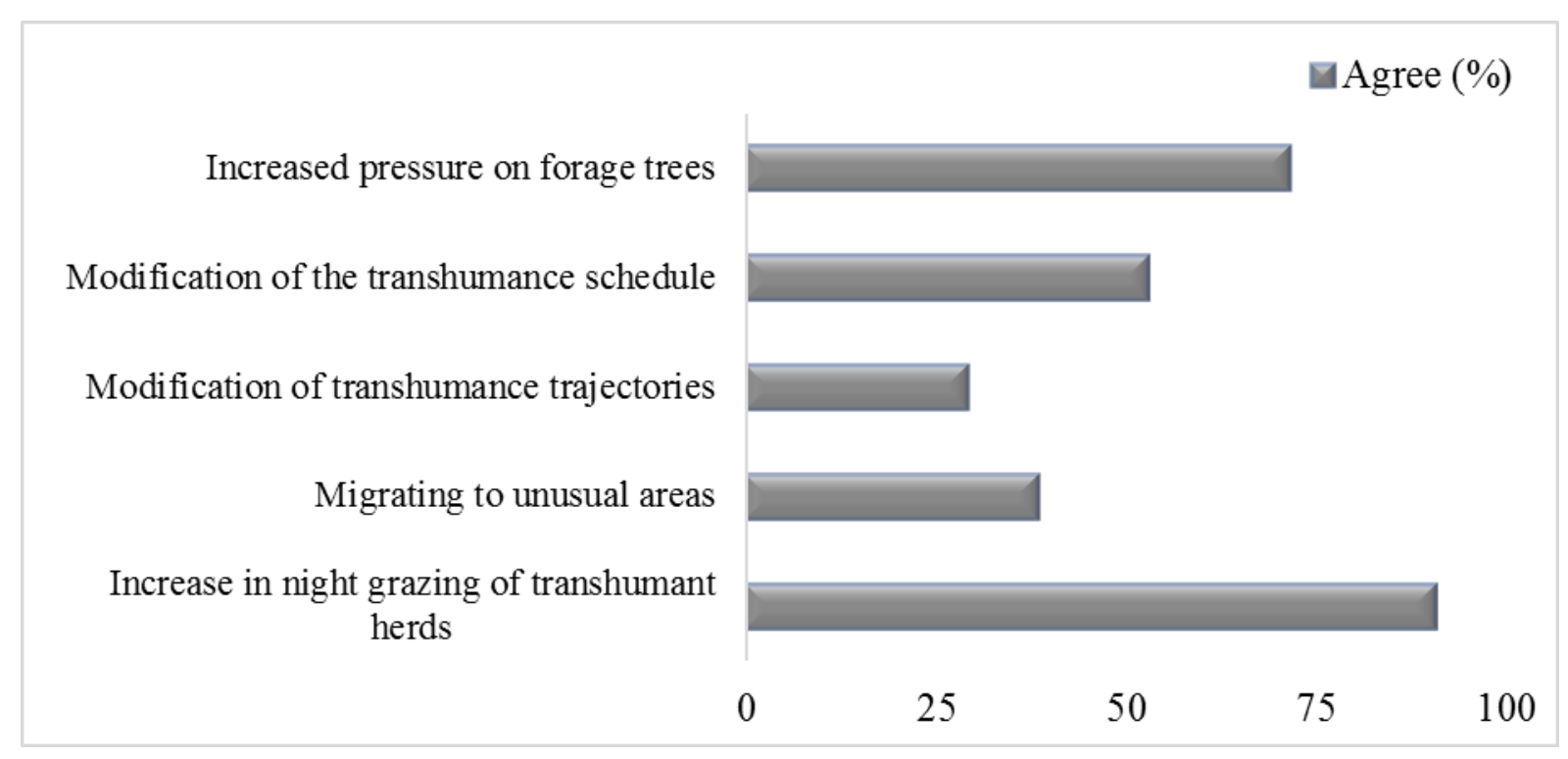

Figure 7. Respondents perceived impacts of LULC dynamics on pastoral practices $(n=271)$

3.4. Respondents adaptation measures to overcome the impacts of land use and cover changes

To adapt to land use and cover changes impacts, pastoralists and agro-pastoralists develop numerous strategies (Table 3). The main strategies are: the increase in rate of cross border transhumance $(98.2 \%)$, shifting to small ruminant species $(42.1 \%)$, the use of agro-industrial by-products $(97.4 \%)$, splitting of herds (91.5\%), diversifying activities (74.9\%), Grazing within protected area $(7.4 \%)$, Fodder cropping (18.1\%), hay harvesting, baling and conservation $(93.0 \%)$ are other practices adopted by respondents. The perception of pastoralists and agro-pastoralists on practices consisting in herds splitting and activities diversification were statistically different at $95 \%$ confident level. However, no difference was recorded in the perceptions of pastoralists and agro-pastoralists regarding other adaptation strategies.

The use of crop residue was not mentioned by herders as adaptation strategy to the reduction of grazing lands. This situation may be due to the fact that all the crop farmers are herding livestock and are likely to reserve their crop residues for their own herds. In such a way, the former collaboration between herders and crop farmers consisting in free grazing on farmers' crops residues is no more frequent. In addition, as mentioned above, in respondents' perspective, transhumance practice was subsequently adopted by herders in Kompienga province only those recent years, because they asserted that Kompienga, thirty years ago, was a destination zone rather than a departure zone of transhumant herds. The amplification of transhumance from the province is fuelled mainly by shrinkage of grazing lands in addition to climate change. Shifting to small ruminant is an adaptation strategy which is gradually taking place. This practice is based on the fact that the needs of small ruminants are easy to be satisfied under conditions of feed scarcity. The use of agro-industrial by-products is depicted as a good adaptation strategy but the socio-economic conditions of herders make this strategy sometime difficult to practice because of their cost-effectiveness with a large herds' size. 


\section{Macrothink}

Splitting herds is a new practice adopted to adapt to the reduction of grazing lands. This practice thirty years ago was seldom. The essence is to constitute small size of herds which easily move but mainly toward different destinations for an efficient exploitation of residual resources in the home in the province and much more toward cross-border countries. Diversifying activities, is also gradually taking place according to the respondents to adapt to decline in grazing lands availability; some other herders asserted that due to the numerous challenges they currently face, they sometimes feel like giving up the activity. Most of the herders are getting into trade as complementary activity.

Grazing within protected areas is a practice that has been gaining momentum in recent years to cope with the phenomena of shrinking of grazing lands. This practice seems to be above the level indicated by respondents $(7.4 \%)$. That situation could be explained by the fact that grazing in protected areas is severely punishable by the law in Burkina Faso through taxes payments and imprisonment of one (1) month to one (1) year (Decree No. 111/PRES of 17March 1997 promulgating Law No. 006197/ADP of 31 January 1997). According to a forest officer in the province, the practice of grazing in protected areas is today one of the major reasons for violent confrontation with herders when they are caught in the act. This practice has become recurrent especially during the night grazing. Fodder cropping, thirty years ago was not a meaningful practice in the mind of respondents.

This practice is taking gradually place within the province especially through the promotion of legume cultivation precisely (Mucuna sp.) by the department in charge of livestock farming and development projects.

The hay making is practiced by great number of herders that help to have forage of acceptable nutritive quality for livestock at the beginning of the dry season prior to transhumance departures. 
Table 3. Respondents' main adopted adaptation measures in pastoral activities $(n=271)$

\begin{tabular}{cccccc}
\hline \multirow{2}{*}{$\begin{array}{c}\text { Strategies adopted } \\
\text { Total }\end{array}$} & & \multicolumn{4}{c}{ Agree (\%) } \\
\cline { 3 - 6 } & Agro-pastoralists & Pastoralists & $\chi^{2}(\mathrm{df} *)$ & p-value \\
\hline $\begin{array}{c}\text { Increase in rate of cross } \\
\text { border transhumance } \\
\quad 98.2\end{array}$ & 43.9 & 54.2 & $2.5(1)$ & 0.117 \\
$\begin{array}{c}\text { Shifting to small } \\
\text { ruminant species }\end{array}$ & 42.1 & 19.2 & 22.9 & $0.004(1)$ & 0.949 \\
$\begin{array}{c}\text { Use of agro-industrial } \\
\text { by-products }\end{array}$ & 97.4 & 44.6 & 52.8 & $0.82(1)$ & 0.365 \\
$\quad \begin{array}{c}\text { Splitting herds } \\
\text { Diversifying activities }\end{array}$ & 91.5 & 39.9 & 51.7 & $3.99(1)$ & $0.046^{*}$ \\
$\begin{array}{c}\text { Grazing within protected } \\
\text { area }\end{array}$ & 7.4 & 38.7 & 36.2 & $13.105(1)$ & $0.000^{*}$ \\
$\begin{array}{c}\text { Fodder cropping } \\
\text { Hay making from natural } \\
\text { grasses }\end{array}$ & 18.1 & 3.7 & 3.7 & $2.65(2)$ & 0.267 \\
\hline
\end{tabular}

*df: degrees of freedom

\section{Conclusion}

The rapid land use and cover changes is affecting pastoral herding and animal husbandry practices in the Kompienga province. Croplands expansion which is increasing affects pastoral resources availability and accessibility through the reduction of grazing lands, the obstruction of livestock routes leading to pasture and watering points. The consequences of these changes are giving place to new practices such as increased use on fodder trees, increase in night grazing of transhumant herds, grazing within protected areas, transhumance into unusual destinations, modification in transhumance routes and schedule.

To overcome these current challenges, most of the pastoralists and agro-pastoralists are adopting certain strategies such as the increase in rate of cross border transhumance, the use of agro-industrial by-products, adoption of hay making, baling and conservation of forage, splitting of herds and livelihoods diversification. Local adaptation strategies are not always sustainable and efficient, it is therefore necessary that some measures be taken at government level to sustain local pastoralists and agro-pastoralists efforts. 


\section{Recommendations and implication for policies in livestock sector in Burkina Faso}

To sustain current local livestock keepers and extension services efforts in livestock sector for the future of pastoralism in the study area as well in the country, a number of measures and policies are needed at local and national level as well as at sub regional. These measures and policies actions include:

(1) preserving the status and rehabilitating the threatened existing grazing reserves, the so called managed pastoral areas. This action may need several steps as followed: (i) inventory of all the pastoral areas threatened and the organization of consultations within the communities to exchange on the issue of pastoral areas. These consultations should involve all the actors: opinion leaders, land owners, herders, crop farmers, traditional leaders and village administrative authorities; (ii) diagnose the root causes of the questioning of pastoral areas (grazing reserves, range lands and herds' routes); (iii) gather in a participatory gait, possible solutions to the management of pastoral areas threatened; (iv) update the limits of the various pastoral areas threatened (grazing reserves, range lands and corridors) and develop their management rules; (iv) census of all occupants of ECOWAS transhumance routes in order to find irrefutable and consensual solutions for their complete and definitive liberation; (v) and provide enough space to herders through the demarcation of new pastoral areas (grazing reserves, livestock routes);

(2) creating enough official grazing reserves and livestock routes within each region of the country, that could reduce and or delay livestock movement towards Kompienga, a destination and transit zone for transhumant herds;

(3) providing all the grazing reserves with necessary facilities such as perennial reservoirs to support forage production by herders. Thus, pastoral areas will be more viable, which could reduce livestock's mobility and related conflicts;

(4) continue the effort of transferring the management of pastoral and grazing areas to local authorities which must design sustainable management schemes;

(5) promoting and implementing the policies with regards to fodder collection from reserves and protected areas. Harvesting fodder from forests and protected areas will have the dual benefit of increasing forage availability for animals and reducing the frequency and magnitude of bush fires.

(6) creating an effective cross-border dialogue framework between Burkina Faso and host countries of transhumant with clear mandate to achieve a diagnosis of the constraints in each municipality crossed by the international transhumance routes; and obtain the formulation of durable solutions with and for the local and pastoral communities which should ultimately reduce conflicts between herders and crop farmers.

\section{Acknowledgement}

We are grateful to the German Federal Ministry of Education and Research (BMBF) who funded this research work through West Africa Science Centre of Climate change and Adapted Land use (WASCAL). We are also grateful to all the respondents and the workers of 
livestock and fishery extension services of Kompienga Province who facilitated the good achievement of our field work.

\section{References}

Blein, R., Soulé, B., Dupaigre, B., \& Yérma. (2008). Agricultural Poten- tial of West Africa. Economic Community of West African States (ECOWAS). Foundation Pour L'agriculture et La Ruralité Dans Le Monde (FARM)., 118.

Boone, A. A., Xue, Y., De Sales, F., Comer, R. E., Hagos, S., Mahanama, S., ... Mechoso, C. R. (2016). The regional impact of Land-Use Land-cover Change (LULCC) over West Africa from an ensemble of global climate models under the auspices of the WAMME2 project. Climate Dynamics, 47(11), 3547-3573. http://doi.org/10.1007/s00382-016-3252-y

Braimoh, A. K., \& Vlek, P. L. G. (2005). Land-Cover Change Trajectories in Northern Land-Cover Change Trajectories in Northern Ghana. Environmental Management, 36(3), 356-373. Retrieved from https://doi.org/10.1007/s00267-004-0283-7

Breiman, L. (2001). Random Forests, 1-33.

Breusers, M. (2001). Searching for livelihood security: Land and mobility in Burkina Faso. Journal of Development Studies, 37(4), 49-80.

http://doi.org/10.1080/00220380412331322041

Dipama, J.-M., Vissin, E. W., Hedible, S., \& Boko, M. (2011). Analyse des stratégies des pratiques agricoles face aux changements climatiques dans la Kompienga (Burkina Faso) et le Mekrou (Benin). Annales de l'Université de Ouagadougou, 13(Série A), 73.

Foody, G. M. (2002). Status of land cover classification accuracy assessment. Remote Sensing of Environment, 80(1), 185-201. Retrieved from

https://doi.org/10.1016/S0034-4257(01)00295-4

Gentle, P., \& Thwaites, R. (2016). Transhumant Pastoralism in the Context of Socioeconomic and Climate Change in the Mountains of Nepal. Mountain Research And Development, 36(2), 173-182. http://doi.org/10.1659/MRD-JOURNAL-D-15-00011.1

Gomgnimbou, A. P. K., Savadogo, P. W., Nianogo, A. J., \& Millogo-Rasolodimby, J. (2010). Pratiques agricoles et perceptions paysannes des impacts environnementaux de la cotonculture dans la province de la Kompienga (Burkina Faso). Sciences \& Nature, 7(2), 165-175. http://doi.org/10.4314/scinat.v7i2.59960

Gonin, A., \& Gautier, D. (2015). Shift in herders' territorialities from regional to local scale: the political ecology of pastoral herding in western Burkina Faso. Springer Open Journal, 5(1), 7. Retrieved from https://doi.org/10.1186/s13570-015-0023-z

IGB \& IGN/IGN-FI. (2015). Document de spécifications externes de contenu de la Base Nationale de Données Topographiques (BNDT), 1-85.

INSD. (2014). Annuaire statistique 2013. Ministère de l'économie et des finances. http://doi.org/10.1007/s13398-014-0173-7.2 INSD. (2008). Recensement General De La 
Population Et De L'Habitation De 2006 (RGPH-2006). Retrieved from

http://www.insd.bf/documents/publications/insd/publications/resultats_enquetes/autres enq/Resultats_definitifs_RGPH_2006.pdf

Judex, M., Thamm, H. P., \& Menz, G. (2003). Modelling of Land-Use Changes in a West African Catchment. Center for Remote Sensing of Land Surfaces, (0). Retrieved from www.isprs.org/proceedings/XXXVI/part7/PDF/069.pdf

Kiema, A., Some, L., Nacro, B. H., Compaore, H., Kagone, H., \& Kpoda, C. S. Y. (2013). Stratratégie d'adaptation des éleveurs de la zone Est du Burkina Faso aux Effets des changements climatiques. Agronomie Africaine Numéro Spécial (6) Sur Les Changements Climatiques, 79(6), 67-79.

Kima, S. A., Okhimanhe, A. A., \& Kiema, A. (2016). Assessing the Impacts of Land Use and land cover change on Pastoral Livestock Farming in South-Eastern Burkina Faso. Environment and Natural Resources Research, 6(1), 110.

http://doi.org/10.5539/enrr.v6n1p110

Kimiti, K. S., Wasonga, O. V., Western, D., \& Mbau, J. S. (2016). Community perceptions on spatio-temporal land use changes in the Amboseli ecosystem, southern Kenya. Pastoralism, 6(1), 24. http://doi.org/10.1186/s13570-016-0070-0

Kioko, J., \& Okello, M. M. (2010). Land use cover and environmental changes in a semiarid rangeland, Southern Kenya. Journal of Geography and Regional Planning, 3(11), 322-326. Retrieved from http://www.academicjournals.org/JGRP

Kioko, J., Kiringe, J. W., \& Seno, S. O. (2012). Impacts of livestock grazing on a savanna grassland in Kenya. Journal of Arid Land, 4(1), 29-35.

http://doi.org/10.3724/SP.J.1227.2012.00029

Kulkarni, A. D., \& Lowe, B. (2016). Random Forest for Land Cover Classification. International Journal on Recent and Innovation Trends in Computing and Communication, $4(3), 58-63$.

Lambin, E. F., Geist, H. J., \& Lepers, E. (2003). Dynamics of land-use and land-cover change in Tropical Regions. Annual Review of Environment and Resources, 28(1), 205-241. Retrieved from https://doi.org/10.1146/annurev.energy.28.050302.105459

Landis, J. R., \& Koch, G. G. (1977). The Measurement of Observer Agreement for Categorical Data. Biometrics, 33(1), 159. http://doi.org/10.2307/2529310

Leblanc M.J., Favreau G., Massuel S., Tweed S.O., Loireau M., Cappelaere B. (2008). Land clearance and hydrological change in the Sahel: SW Niger. Glob Planet Change 61:135-150. doi:10.1016/j.gloplacha.2007.08.011

Maina, W., \& Mundia, C. N. (2016). Impact of land use land cover change and climate variability on pastoral grazing resources in Kajiado county , Kenya. INTERNATIONAL JOURNAL OF GEOMATICS AND GEOSCIENCES, 7(1), 104-115. 
MBayngone, E. (2008). Flore et Vegetation de la Reserve partielle de faune de Pama, sud-est du Burkina Faso.

Mbayngone, E., Thiombiano, A., Hahn-Hadjaki, K., \& Guinko, S. (2008). Structure des ligneux des formations végétales de la Réserve de Pama ( Sud-Est du Burkina Faso, Afrique de 1 ' Ouest ). Flora et Vegetatio Sudano-Sambesica, 11, 25-34. Retrieved from https://www.researchgate.net/publication/290306433

Msoffe, F. U., Kifugo, S. C., Said, M. Y., Neselle, M. O., van Gardingen, P., Reid, R. S., ... de Leeuw, J. (2011). Drivers and impacts of land-use change in the Maasai Steppe of northern Tanzania: An ecological, social and political analysis. Journal of Land Use Science, 6(4), 261-281. http://doi.org/10.1080/1747423X.2010.511682

Nacoulma, M. B. I., Traoré, S., Hahn, K., \& Thiombiano, A. (2011). Impact of land use types on population structure and extent of bark and foliage harvest of Afzelia africana and Pterocarpus erinaceus in Eastern Burkina Faso, 3(3), 62-72.

Ouedraogo, I. (2010). Land Use Dynamics and Demographic Change in Southern Burkina Faso. Swedish University of Agricultural Sciences Alnarp.

Ouedraogo, I., Savadogo, P., Tigabu, M., Cole, R., Odén, P. C., \& Ouadba, J. M. (2009). Is rural migration a threat to environmental sustainability in Southern Burkina Faso? Land Degradation and Development, 20(2), 217-230. Retrieved from

https://doi.org/10.1002/ldr.910

Ouedraogo, I., Tigabu, M., Savadogo, P., Compaoré, H., Odén, P. C., \& Ouadba, J. M. (2010). Land cover change and its relation with population dynamics in Burkina Faso, West Africa. Land Degradation and Development, 21(5), 453-462. http://doi.org/10.1002/ldr.981

Sanou, C. L., Tsado, D. N., Kiema, A., Eichie, J. O., \& Okhimamhe, A. A. (2018). Climate Variability Adaptation Strategies : Challenges to Livestock Mobility in South-Eastern Burkina Faso. Open Access Library Journal, 5(e4372), 16. http://doi.org/10.4236/oalib.1104372

Sawadogo, I. (2011). Ressources fourragères et représentations des éleveurs, évolution des pratiques pastorales en contexte d'aire protégée: Cas du terroir de Kotchari a la périphérie de la réserve de biosphère du $\mathrm{W}$ au Burkina Faso. Thèse de Doctorat, Museum National D'histoire Naturelle, 336.

Soulama, S. (2016). Types d'utilisation des terres et indicateurs de dégradation de la biodiversité dans les réserves de Pama et les agrosystèmes (Sud-est du Burkina Faso). Thèse de Doctorat, Université Ouaga I Pr Joseph KI - ZERBO, Burkina Faso, 165p.

Soulama, S., Kadeba, A., Nacoulma, B. M. I., Traoré, S., Bachmann, Y., \& Thiombiano, A. (2015). Impact des activités anthropiques sur la dynamique de la végétation de la réserve partielle de faune de Pama et de ses périphéries ( sud-est du Burkina Faso ) dans un contexte de variabilité climatique. Journal of Applied Biosciences, 87, 8047-8064.

http://doi.org/10.4314/jab.v87i1.6

Sulieman, H. M., \& Elagib, N. A. (2012). Implications of climate, land-use and land-cover 


\section{Macrothink}

Journal of Agricultural Studies

ISSN 2166-0379

2018, Vol. 6, No. 3

changes for pastoralism in eastern Sudan. Journal of Arid Environments, 85, 132-141. http://doi.org/10.1016/j.jaridenv.2012.05.001

Western, D. (2006). A half a century of habitat change in Amboseli National Park, Kenya. African Journal of Ecology, 45(3), 302-310.

http://doi.org/10.1111/j.1365-2028.2006.00710.x

Western, D., \& Maitumo, D. (2004). Woodland loss and restoration in a savanna park: a 20-year experiment. African Journal of Ecology, 42(2), 111-121.

Western, D., \& Nightingale, D. L. M. (2003). Environmental Change and the Vulnerability of Pastoralists to Drought: A Case Study of the Maasai in Amboseli, Kenya. Africa Environmental Outlook Report. Nairobi. Retrieved from

www.oceandocs.org/bitstream/handle/1834/436/Amboseli_maasai.pdf?sequence=1

Wood, E. C., Tappan, G. G., \& Hadj, A. (2004). Understanding the drivers of agricultural land use change in south-central Senegal. Journal of Arid Environments, 59, 565-582. Retrieved from https://doi.org/10.1016/j.jaridenv.2004.03.022

Zampaligré, N., Dossa, L. H., \& Schlecht, E. (2013). Climate change and variability: Perception and adaptation strategies of pastoralists and agro-pastoralists across different zones of Burkina Faso. Regional Environmental Change, 14(2), 769-783.

http://doi.org/10.1007/s10113-013-0532-5

ZATE, 2015. Rapport d'inventaire et d'évaluation des dégâts en relation avec les ressources animales survenu le 17 /01/2015 dans cinq villages de la province de Kompienga. 8p.

\section{Copyright Disclaimer}

Copyright for this article is retained by the author(s), with first publication rights granted to the journal.

This is an open-access article distributed under the terms and conditions of the Creative Commons Attribution license (http://creativecommons.org/licenses/by/4.0/). 